\title{
トランスレーショナル・リサーチに期街する
}

\section{Hope in translation}

\author{
2010 年 9 月 30 日号 Vol. 467 (499)
}

多くの生物医学研究者が、自らの着想を人間で検証し始めている。

こうした初期段階の臨床試験結果は、研究者と臨床医の協力関係がより前進する確かな予兆といえる。

Nature の読者は楽観的な思考の持ち主 に違いない。毎週、病気や健康障害との 戦いが続く現場からの明るいニュースが 掲載されるからだ。しかし、効率よく治 療できる人間の病気は今でも少ないし、 先進国の高齢化によって迫り来る保健分 野の負担を考えれば、正直いって、力不 足の感は否めない。特に不安なのは、研 究者と臨床医が、生物学の基礎研究の成 果を治療法に転換できていないこと、ま た、そうした転換があまり成功しない理 由を明らかにできていないことだ。これ ら 2 つの問題は、臨床研究を発展させ るうえでの障害となっている。

トランスレーショナル・リサーチ（橋 渡し研究）の意義は、まさにここにある。 この考方方は、ここ 10 年間、資金提供 機関が、基礎実験室と臨床現場のギャッ プを埋める方法として強力に推進して きたものだ。ハイリスク・ハイリターン の研究を促し、必要なッールや手法の開 発、知識格差の解消を進め、協力関係を 醸成するよう大学の風土を変えるため に、助成金が新設された。トランスレー ショナル（橋渡し）という言葉はまさに 絶妙だった。基礎研究者と臨床医では、 しゃべる言葉が違う。2つのコミュニ ティーに共通の言語はなく、両者は分断 されていたのだ。

このほど、トランスレーショナル・リサー チから驚くべき成果が得られることを示 す論文が発表され (K. T. Flaherty et al. N. Engl. J. Med. 363, 809-819; 2010)、 Nature 2010 年 9 月 30 日号 596 ページ の Bollag らの論文では、その詳細が記さ
れている。

Bollag らは、メラノーマ治療薬の初 期臨床試験を行い、全患者 32 人中、24 人で腫瘍が少なくとも $30 \%$ 退縮し、2 人については腫瘍が完全に消えたと報告 している。これほどの成果は、標準的な 臨床試験の初期段階ではほとんど考元ら れない。この差を生んだのがトランス レーショナル・リサーチというアプロー チだった。

Bollag らの臨床試験のもとになった のは、メラノーマ患者の $60 \%$ 以上に、 B-RAF タンパク質をコードする遺伝子 の変異があるという 2002 年の発見だっ た。この変異が、がん細胞の増殖を促進 するシグナル伝達経路の引き金となるの だ。Bollag らは、メラノーマ患者に対し、 B-RAF の変異の有無を調べるスクリー ニングを行い、B-RAFに変異をもつ患 者に対してのみ、変異遺伝子の活性を阻 害する実験薬を投与した。この方法は明 確な仮説に基づいており、研究者にとつ ては当たり前のように聞こえるかもしれ ない。ところが、このような方法による 臨床研究は、これまで行われてこなかっ たのだ。今回の研究がなければ、ほとん どの臨床試験において、個人としての患 者ではなく、従来どおりの万人一律の方 法、つまり集団の一員として患者を治療 するやり方が踏襲されていたであろう。

がんは均一な疾患ではなく、複雑で不 均一な疾患であることが基礎研究から判 明している。この知識を利用して、仮説 に基づいた別の臨床試験が同様の成功を おさめている。それは、分子生物学を用
いて患者を区分する、というものだ。一 例が、BRCA1 または BRCA2 のいずれ かの遺伝子が変異している卵巣がん患者 やその他のタイプのがん患者に対して、 PARP 阻害剂を投与する臨床試験だ。

研究機関や大学は病院との提携を進め ており、また、基盤整備によって臨床研 究者と基礎研究者とのコミュニケーショ ン改善が奨励されている。プロテオミク ス、ゲノミクス、バイオマーカー、疾患 の高分解能プロフィール、幹細胞などは、 いずれも病気の治療法を改善させる可能 性を秘めており、いずれも基礎研究者が 先駆となって研究を進めてきた。現在の トランスレーショナル・リサーチに対す る助成制度では、同じ研究チームが、臨 床現場でその成果が利用されるまで研究 を続けられるようになっている。今後数 年の間に、研究者の中で、トランスレー ショナル・リサーチに関与する人の割合 が増えると Nature は予想する。

既に Nature は、初期臨床試験の成功 につながった前臨床研究論文を、いくつ か掲載してきた。Nature には、臨床試 験自体の結果を報告する場としての伝統 はないが、こうした初期臨床試験結果が 読者にとってますます大事になっている ことは認識している。したがって、この 分野での質の高い論文投稿を歓迎した い。生物学に基づき、患者の応答という 観点で有望な臨床試験の結果は、病気と の闘いにおける流れを変える助けとなる だろう。道のりは長いだろうが、楽観的 な思考を持ち続けたいと思う。

(翻訳 : 菊川要) 